\title{
The US Money Explosion of 2020, Monetarism and Inflation: Plagued by History?
}

\author{
Richard C. K. Burdekin \\ Claremont McKenna College, Claremont, USA \\ Email: richard.burdekin@claremontmckenna.edu
}

How to cite this paper: Burdekin, R. C. K. (2020). The US Money Explosion of 2020, Monetarism and Inflation: Plagued by History? Modern Economy, 11, 1887-1900. https://doi.org/10.4236/me.2020.1111126

Received: October 5, 2020

Accepted: November 21, 2020

Published: November 24, 2020

Copyright $\odot 2020$ by author(s) and Scientific Research Publishing Inc. This work is licensed under the Creative Commons Attribution International License (CC BY 4.0).

http://creativecommons.org/licenses/by/4.0/

\begin{abstract}
Although the Federal Reserve's quantitative easing of early 2020 was comparable in scale to 2008-2009, the implications for the growth of money in circulation and future inflationary pressures appear quite different. Absent the unprecedented surge in bank excess reserve ratios seen in 2008 and after, massive monetary base increases imply the possibility of a much larger, and potentially worrisome, increase in the money in circulation. Rising inflation expectations are implied by such phenomena as the surging demand for Treasury Inflation Protected Securities and record highs for gold prices during the summer of 2020. These trends lend some support to market participants evincing concern that the surging money growth is, in fact, a precursor to future inflation. Historical perspective on the 2020 situation is provided by data from the time of the 1918-1919 Spanish flu and available documentation of inflation following medieval and Roman-era pandemics. Indications of extra upward pressure on prices arising from pent-up spending after the epidemic has passed include the surge in bank loans in the aftermath of the 1918-1919 Spanish Flu pandemic.
\end{abstract}

\section{Keywords}

Monetary Policy, Coronavirus, Inflation, Monetarism, Spanish Flu, Plague

"Numerous as are the disasters which normally lead to the decay of Kingdoms, principalities, and republics, the four ... most to be feared: war, disease, famine, and inflation. No person can ignore the evidence of the first three, but very few people ... bother themselves about the fourth cause ... because it operates not by a sudden blow, but with a stealthy and hidden power it gradually works the overthrow of states."

(Nicholas Copernicus, 1473-1543) $^{1}$

${ }^{1}$ Quotation given in Taylor (1955: p. 543). 


\section{Introduction}

The Federal Reserve's initial response to the coronavirus pandemic was larger in absolute size than its response to the Global Financial Crisis. The monetary base increase of $\$ 1390$ billion between February and April 2020 alone was greater than the aggregate total monetary base at the end of October 2008. On a percentage basis, the 2008-2009 monetary base expansion remains the most remarkable, however. The near doubling of the monetary base between September 2008 and January 2009 meant that the Federal Reserve printed almost as much money in those four months as it had over its entire prior 95-year history. At the same time, the monetary base rise from $\$ 909$ billion to $\$ 1712$ billion vastly outstripped the increase in money in circulation. Over these same four months, the M2 money supply increased from $\$ 7936$ billion to $\$ 8238$ billion, i.e., less than $4 \%$. This, in turn, reflected the equally unprecedented rise in commercial bank excess reserve levels, which skyrocketed from near zero to above $90 \%$ as banks became increasingly unwilling to loan as the crisis took hold. This meant that very little of the new money created by the Federal Reserve actually made it into circulation, leading to the vastly different trajectories of base money and M2 seen in Figure 1 where the monetary base exploded upward after September 2008 even as the trend in M2 growth remained little altered.

The lack of inflation after 2008 certainly cannot be taken of proof that money no longer matters. Although a declining velocity of circulation did play some role, the key point is that the decline in the money multiplier largely offset the enormous increase in base money. The Federal Reserve's quantitative easing was critical in avoiding the type of monetary contraction that occurred in the early

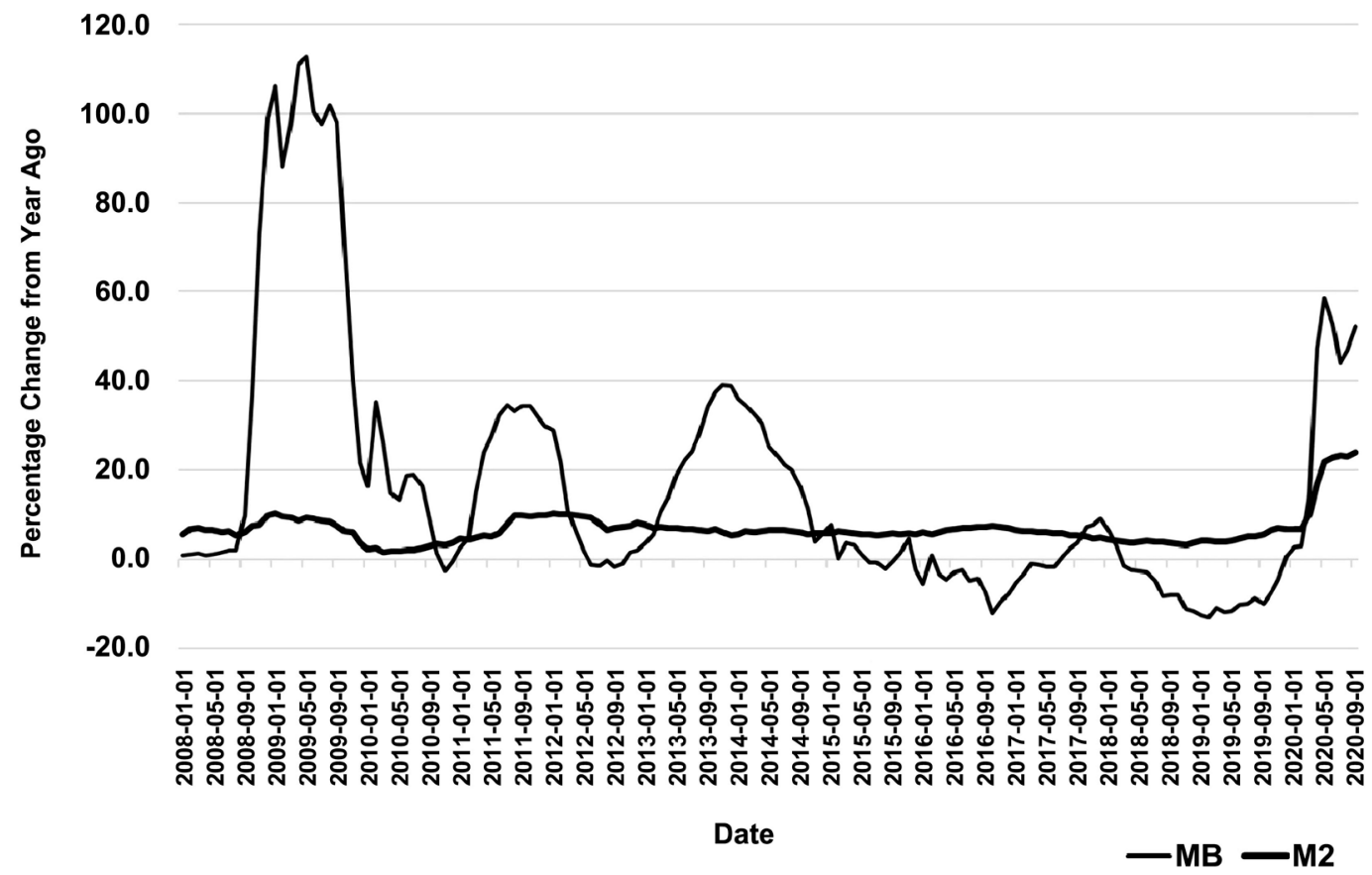

Figure 1. Monetary base growth vs. M2 money supply growth, January 2008-September 2020. 
1930s. Inflationary consequences remained minimal, however, owing to the soaring excess reserve ratios that greatly constrained the overall money supply increase at this time. By contrast, absent such extraordinary increases in bank reserve holdings, the initial consequences of the 2020 expansion differ markedly from the 2008-2009 case. Between February 2020 and September 2020, the monetary base rose from $\$ 3454.5$ billion to $\$ 4880.4$ billion while M2 rose from $\$ 15,446.9$ to $\$ 18,647.9$ billion. $^{2}$ Although the $41.3 \%$ increase in the monetary base over these seven months is behind the pace of 2008-2009, the M2 response was an order of magnitude greater and it registered an increase of $20.7 \%$ between February and September. If maintained for a full year, this would be equivalent to an annualized $36.2 \%$ rate of increase.

\section{2020 Quantitative Easing and Its Effects}

In addition to swiftly reintroducing a zero interest rate policy, the Federal Reserve's March 2020 policy moves included the reinstitution of a number of the facilities previously created to address the Global Financial Crisis, such as the Commercial Paper Funding Facility and the Primary Dealer Credit Facility (see Edwards, 2020, for a detailed timeline). The Federal Reserve also expanded its US dollar liquidity swaps and created a repurchase facility to aid dollar-denominated lending by international monetary authorities. Major new measures included over $\$ 2$ trillion in lending facilities for municipalities, corporations, and small and medium-sized enterprises (SMEs). Federal Reserve lending to private firms under the Coronavirus Aid Relief and Economic Security Act (US Congress, 2020), or CARES Act, was undertaken in conjunction with the US Treasury and went well beyond the normal bounds of monetary policy. The newly introduced juxtaposition between the Treasury and the Federal Reserve is reflected in the fact that the CARES Act created a $\$ 454$ billion fund that the Treasury must invest in programs or facilities established by the Federal Reserve.

As pointed out by Hetzel (2020), this not only involved the Federal Reserve regulating the flow of credit to particular sectors of the economy but also exposed the Federal Reserve to losses associated with loans made under these new programs. Although the CARES Act essentially covers the first $10 \%$ of any such losses, Hetzel (2020: p. 30) points out that regardless of whether or not the loss is actually booked to the Federal Reserve "it is a loss of government revenue ... [that] increase[s] the deficit and the issuance of Treasury debt, which competes for private spending." The extent of the lending made possible under the CARES Act is huge and could be potentially leveraged up to $\$ 2$ trillion, posing a threat to Federal Reserve independence insofar as "Congress has an incentive to transfer risk to the Fed's books where it is invisible to taxpayers" (Hetzel, 2020: p. 35).

Unlike in 2008-2009, the barrage of quantitative easing measures was accompanied by policies designed to increase bank lending. On March 15, 2020, the

${ }^{2}$ These figures, like those employed in Figure 1 and Figure 2, are drawn from the Federal Reserve Bank of St. Louis' FRED database. 
Federal Reserve eliminated reserve requirements and encouraged banks to use capital and liquidity buffers to lend to households and businesses. This stands in stark contrast to the introduction of interest payments on bank reserves in 2008 that contributed to the soaring excess reserve ratios seen at that time with bank reserves quickly rising from $\$ 10$ billion in 2008 to over $\$ 1$ trillion after $2009 .^{3}$ In short, whereas the 2008-2009 policies tended to lower the money multiplier, the 2020 measures worked towards raising it or at least offsetting any inherent tendency for it to decline. The relaxation of bank capital requirements to foster lending was itself undertaken in 2020 not just by the Federal Reserve, but also the Bank of England, Bank of Japan and European Central Bank.

The early tendency for much greater correspondence between money supply and monetary base increases in 2020 is evident in Figure 1. It is true that this was at first accompanied by downward, not upward, pressure on the rate of consumer price inflation (Figure 2). ${ }^{4}$ Declining spending, and declining velocity of circulation, remain an inevitable initial consequence of crisis, rising uncertainty and job loss. In this, although the 2008-2009 and 2020 cases share similarities, the pandemic produced further involuntary savings due to the unavailability of most leisure and entertainment activities and, for a time, the closure of many shops, combined with income losses for those employed in the sectors being shut down (Goodhart, 2020). However, US consumer price inflation steadily ticked higher from its low of $0.2 \%$ in May 2020, ending the summer at $1.4 \%$ in September 2020. At the same time, the risks of sustained deflation, at opposed to temporary price declines of the type seen in the aftermath of the Global Financial Crisis, appear to have remained low even at the most tumultuous times of early 2020. Based on analysis of the information contained in nominal and real government bond yields through the end of March 2020, Christensen et al. (2020) find that perceived deflation risks remained essentially unchanged not only in the United States but also in Canada, France and Japan. Meanwhile, Apergis \& Apergis' (2020) analysis of daily swap inflation rates from January-July 2020 suggest that US inflation expectations actually rose following the onset of the pandemic.

Figure 2 suggests that the relationship between money and prices began to be re-established after the Global Financial Crisis had passed. Following their divergent trends in 2008-2009, money and prices both increased in 2010-2011 followed by a shared modest decline that persisted until 2016. A renewed divergence in 2019 expanded greatly in 2020 as the negative pressures on spending and the velocity of money associated with the pandemic kept inflation low even as the rate of monetary expansion soared. The forces constraining the inflationary

${ }^{3}$ This not only lowered the money multiplier but also entailed a move from a "corridor system" to a "floor system" for interbank rates. The post-2008 framework eliminates any incentive for banks to lend in the interbank market below the rate of interest paid by the Federal Reserve on their reserve deposits in line with similar moves being undertaken by other central banks in the 2000s (Terzi, 2015).

${ }^{4}$ Figure 1 and Figure 2 display the year-on-year percentage changes in each series, using data from the Federal Reserve Bank of St. Louis' FRED (2008-2020) database. 


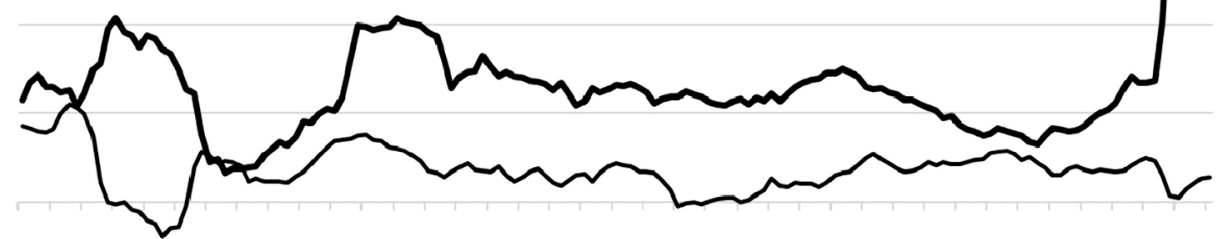

$-5.0$

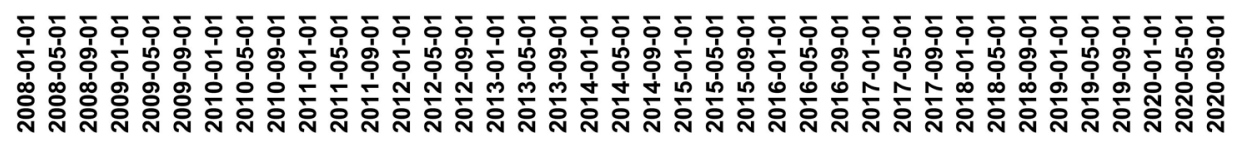

Date

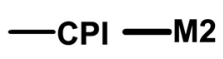

Figure 2. M2 money supply growth vs. CPI inflation rate, January 2008-September 2020.

consequences of such rapid money growth in 2020 cannot last indefinitely, however. As the shutdowns ease and workers in the most affected sectors begin to be rehired, the main factors offsetting inflationary effects of massive money issuance will wither away. This still need not necessarily lead to major inflationary problems so long as the Federal Reserve and other central banks respond by reigning in money supply growth and raising interest rates. However, as argued by Goodhart (2020), this may not be easily done in an environment where unemployment remains at historically high levels and government deficit and debt ratios are at extremes more typical of wartime. The effects of the rapid rates of monetary expansion may already be manifested not just in the modest uptick in consumer price inflation but also the stock market boom that followed the lows of March 2020. This would be consistent with the past experiences considered by Friedman (2005), who links the US stock market recovery from the post-1999 crash to rapid Federal Reserve monetary expansion and contrasts this with the effects of stagnant money supply in post-1989 Japan and monetary contraction in the post-1929 US case.

Another indicator of excess liquidity today, as well as potential inflation risks, can be found in the more than $25 \%$ rise in gold prices in the first six months following the onset of the crisis. Gold prices advanced from \$1564.1/ounce at the end of February 2020 to $\$ 1966.4$ /ounce at the end of August 2020 and breached the $\$ 2000 /$ ounce level for the first time ever earlier in August. Although gold prices are certainly not driven by inflationary expectations alone, rising gold demand was accompanied by rising demand for indexed bonds. Indeed, yields on 30-year Treasury inflation-protected securities (TIPS) were driven to record 
lows and actually fell below zero in July 2020. Even as the stock market continued to rise, money flowed back in to funds investing in TIPS and inflows of over $\$ 5$ billion were seen in a single week in July 2020 (Mackenzie, 2020). Meanwhile, weakness in the US dollar since its highs of March 2020 was accompanied by rising oil prices and other commodities in addition to the aforementioned strength in gold.

Examination of prior pandemics such as the 1918-1919 Spanish Flu not only suggests that inflation followed monetary expansion once the epidemic was over but also that pent-up spending and increased demand for bank loans then served to exacerbate the inflationary pressures. Accordingly, rising velocity of circulation and a rising money multiplier may need to be factored in. None of this is to say that the extraordinary quantitative easing was not both needed and warranted (Greenwood \& Hanke, 2020), but that we cannot be too blasé about the inflation risk and should not be relying just on the 2008-2009 experience as a guide. Another factor coming into play as the economy re-opens in 2020 concerns upward pressure on prices associated with the need to cover the expense of the new safety and hygiene measures as well as rising food costs (see Grossman, 2020). And, as discussed below, the threat of inflation following the onset of a pandemic would certainly not be anything new.

\section{Lessons from the 1918-1919 Spanish Flu}

The 1918-1919 pandemic, widely referred to as the "Spanish Flu," began in March 1918 during the last year of World War I and may have caused the death of over 50 million worldwide. The first springtime wave proved far less fatal than a second wave that spread around the world from September through November 1918. Many nations also experienced a third, and final, wave in early 1919. US death rates in 1918 were 5 - 20 times higher than expected under typical seasonal influenza and these deaths were also unusually concentrated in younger age cohorts with the highest exposure being for those in their twenties and early thirties (see, for example, Taubenberger \& Morens, 2006). Any assessment of the economic effects of the Spanish Flu is complicated by the fact that the first two waves occurred while World War I was still in progress. Continuing for some months after the Armistice of November 11, 1918, the remainder of the pandemic is then conflated with the effects of demobilization and a return to peacetime production. ${ }^{5}$ Although the pandemic's onset was accompanied by relatively expansionary monetary policy, this primarily reflected a continuation of the Federal Reserve's wartime focus on interest rate pegging. The Federal Reserve's "unwillingness to see a decline in the prices of government bonds" persisted into 1919 in part because "commercial banks still held on their own account substantial amounts of the Victory Loan, floated from April 25 to May 10, 1919 ..." (Friedman \& Schwartz, 1963: pp. 223-224).

Notwithstanding the much higher death rate, output effects of the Spanish Flu ${ }^{5}$ Significant stock market effects of the rising death rates are, however, identified in the ten-country sample analyzed in Burdekin (2020). 
appeared to be only short-lived and primarily reflected in a negative labor supply shock (Velde, 2020). Financial disruption also appeared to be short-term in nature. Whereas banks located in areas more severely affected by the pandemic initially experienced deposit withdrawals, these were soon followed by renewed inflows as 1919 progressed and the banking system was quickly able to fully recover (Anderson, Chang, \& Copeland, 2020). Although some familiar containment measures were applied, including closing churches, schools and places of entertainment, banning mass gatherings and requiring masks, the application of these controls was uneven across the country and considerably shorter in duration than in 2020. Restrictions were rarely maintained for much more than a month (see Bootsma \& Ferguson, 2007: Appendix). The war effort remained a complication, especially limiting the potential restrictions in New York City given that it was the main departure point for troops heading to Europe with President Woodrow Wilson insisting that transports continue even as the epidemic hit hard in October 1918 (Spinney, 2017: p. 104). Nevertheless, one indicator of the impact on leisure spending is perhaps Major League Baseball attendance. Overall attendance fell by over 50\% from 4,762,705 in 1917 to 2,830,613 in 1918 before more than doubling to $6,532,439$ in 1919 after the pandemic came to an end. ${ }^{6}$

The possibility that the baseball data are indicative of a more far reaching pent-up demand could help explain the fact that, after the pandemic came to an end, rising bank loans financed a "speculative orgy of 1919" (Wicker, 1966: p. 236). Even as the Federal Reserve maintained an unchanged discount rate, this policy had far from neutral effects given that the strong demand for loans at this time meant that it was "profitable for commercial banks to expand the stock of money at the then existing discount rate" (Friedman \& Schwartz, 1963: p. 223). This was accompanied by high levels of member-bank borrowing that subsequently deterred the Federal Reserve from reducing discount rates even as deflation set in during 1920. As shown in Figure 3, money supply and prices rose together from 1915 through the end of 1919, prior to entering the sharp but relatively short-lived deflation of 1920-1921.7 There was a slackening of both money and price increase around the time of the second wave of the Spanish Flu in late 1918 followed by a renewed acceleration in both series through most of 1919 . Whether the temporary pause was actually driven by effects of the epidemic is unclear. The timing of the 1919 surge remains interesting, however, given that the re-acceleration in money and price growth is delayed until March 1919 even though the war ended in November 1918. Although a number of cities removed their restrictions in October or November 1918, others such as Kansas City, Milwaukee, San Francisco, Spokane and St. Louis continued interventions into January or February 1919 (Bootsma \& Ferguson, 2007: Appendix).

${ }^{6}$ Data drawn from BallparksofBaseball.com.

${ }^{7}$ The money supply data are from Friedman \& Schwartz (1963: pp. 708-711) and the CPI data are from Global Financial Data. For the purposes of the diagram, the raw M1 data were divided by 1150 to produce a starting value similar to that of the CPI series. Although broader M2 money supply received more emphasis today, this alternative money supply series is not available for the earlier era. 


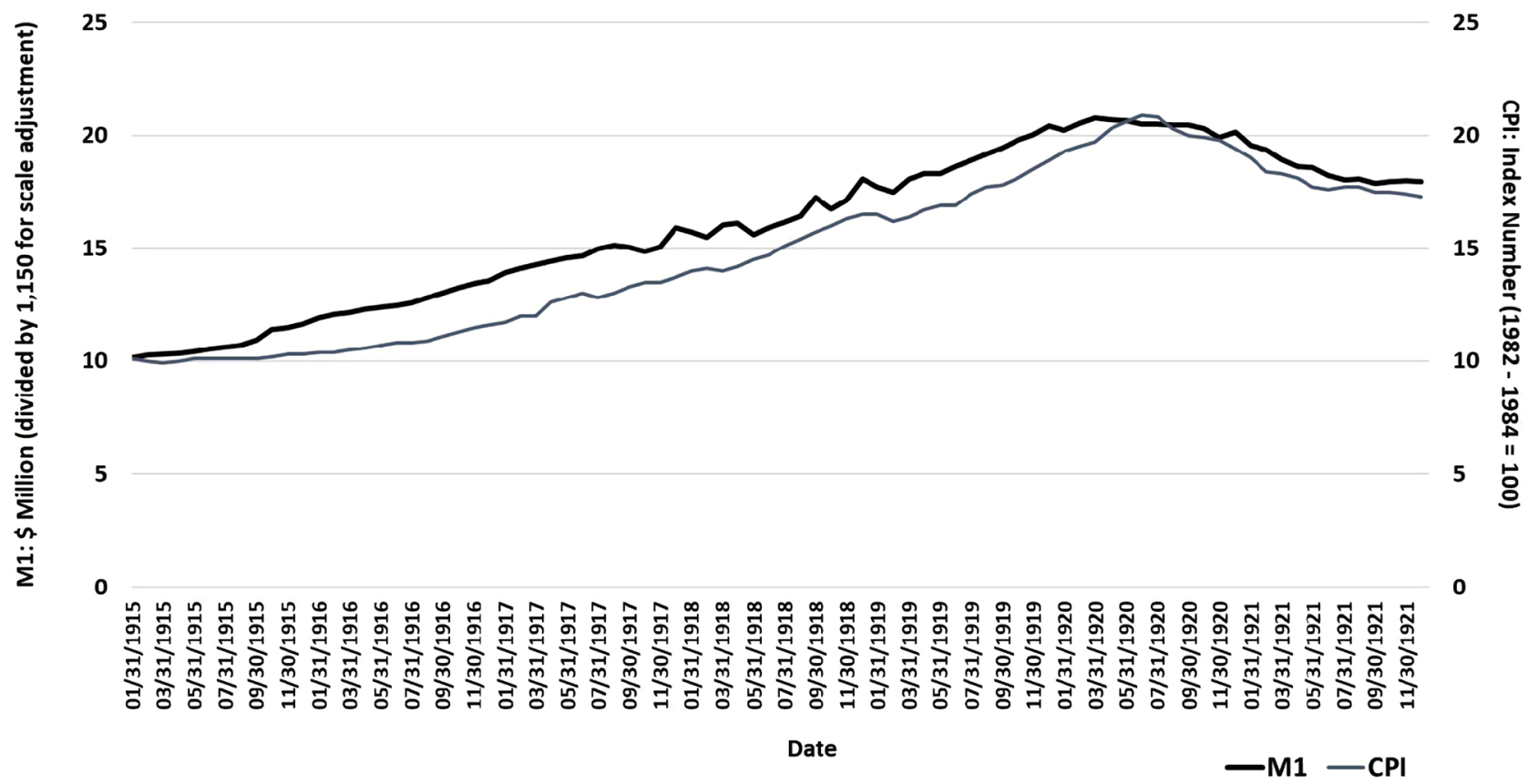

Figure 3. M1 money supply vs. consumer price index, 1915-1921.

A positive takeaway from the Spanish Flu experience is that pandemic-induced spending reductions need not be deflationary so long as there is sufficient monetary expansion-and we now have ample evidence that deflation is much harder to reverse than inflation (see, for example, Burdekin, 2018, and the references cited therein). However, the post-World War I experience also highlights the danger of delayed inflationary effects of monetary expansion. The inflationary problems that emerged in the face of the rising bank lending after the pandemic came to an end suggests that the usual causal relationship between money and prices reasserted itself in the same way that such observers as Goodhart (2020) anticipate in the aftermath of the coronavirus. The importance of this monetary side of the equation is further reflected in the fact that deflation, although avoided in 1918-1919, subsequently emerged in 1920-1921 at the very time that the Federal Reserve changed course and oversaw a monetary contraction that, in retrospect, represented an unfortunate prelude of what was to come in 1930-1933. Available data suggest that analogous monetary calculus may be applicable to earlier pandemics except that, in even more catastrophic cases such as the Black Death, the sudden loss of as much as $40 \%$ of the population shifts the focus towards money supply per capita-which automatically increased as the plague swept through the country.

\section{Earlier Pandemics in Medieval and Roman Times}

Although there were a number of subsequent recurrences, the main onslaught of the Black Death occurred during 1347-1349. At first, the dominant effect appears to have been the drastic loss of demand in the face of the enormous, and sudden, death toll with wheat prices in England believed to have fallen by $35 \%$ 
between 1347 and 1348 (see Paarlberg, 1993: p. 13). Supply shortages soon combined with higher per capita money stocks to drive prices higher, however. English wheat prices, for example, rose above the pre-plague levels by 1350 and there was a more than $138 \%$ price increase between 1348 and 1351. In addition to the role played by money and output, there are also indications of higher discretionary spending that may have some parallels with what was observed in 1919 in the aftermath of the Spanish Flu. In particular, the Black Death appears to have fostered a "fatalistic yet hedonistic spending spree, facilitated all the more by suddenly inherited cash balances" (Munro, 2004: p. 13). Insofar as this implies a rise in the velocity of circulation after 1349 , its actual contribution to inflation has to be set against the inflationary effects of the extensive currency debasements undertaken by most European countries at this time. ${ }^{8}$ Nevertheless, the suggestion of post-plague increases in spending rates reinforcing the inflationary consequences of monetary expansion is in line with what can be deduced from the Spanish Flu case. ${ }^{9}$ In particular, both these historical episodes suggest that, while falling velocity may offset inflationary pressures during the height of the pandemic, the situation was reversed as the pandemic came to an end. As the main inflation checks were removed, prices rose in conjunction with the increasing per capita money stocks of the Black Death just as was true in the face of the rising bank loans of 1919.

The first documented major pandemic, longer lasting then even the Black Death, was experienced at the height of the Roman Empire. The devastating Antonine plague is believed to have killed as much of a third of the population between $\mathrm{AD} 165$ and 180. It was as close to a worldwide pandemic as was possible in those times, with similar outbreaks recorded in Central Asia as well as China - which was by then connected with Rome via trade routes (McLaughlin, 2010). The onset of the plague was associated with a sharp drop in coin mintage in Rome in AD 167 and in Egypt from 166-168. However, this was followed by a strong and sustained recovery after 167 at the Rome mint coupled with substantially increased minting in Egypt during 169-170 (Duncan-Jones, 1996: pp. 130-134). Meanwhile, Temin (2013: p. 85) points to the plague driving prices higher as reduced goods production was reinforced by increased money per capita owing to the drastic reduction in population. Rathbone (2007: p. 713) documents the increase in Egyptian wages and prices in the years following the onset of the plague as follows:

The sharp doubling of prices and wages in the later second century is best explained as a sign of temporary economic dislocation caused by the Antonine Plague.

${ }^{8}$ These debasements were sometimes "severe enough to promote a veritable 'flight from coinage"” (Munro, 2004: p. 13).

${ }^{9}$ Longer-run effects of the Black Death, Spanish Flu and other pandemics are examined by Jordà, Singh, \& Taylor (2020), who found evidence of sustained reductions in real rates of return combined with upward pressure on real wages. Barro, Ursua, \& Weng's (2020) cross-country study also identifies negative effects on real returns arising from the Spanish Flu, along with consumption and GDP declines. 
The extent of the price increase seems far out of proportion with the population decrease, however. As noted by Temin (2013: p. 88):

Prices needed only have risen by about one-third to equalize the per capita money stock if that were the only cause of inflation.

Although cost-push inflation pressures owing to supply shortages undoubtedly played some role, it is possible that Egyptian prices were also responding to currency debasement of the Alexandrian tetradrachm. The extent of the debasement appears to be substantial, with Howgego et al. (2013) suggesting that the silver content reflected in the coin's "fineness" declined from 18\% during the pre-plague years to just $5 \%$ by $167-168$. Following a partial recovery to $10 \%$ fineness that appears to have lasted from approximately 170 until 180-181, this $5 \%$ level returned again. ${ }^{10}$ Although available data remain very limited, the debasement and sharp price increase following the onset of the plague contrast sharply with the "striking" stability in Egyptian wheat prices prior to AD 165 (Harper, 2016: p. 815), which was, of course, the first plague year. ${ }^{11}$ Temin (2013: p. 88) also notes that, while the ensuing inflation increase in Egypt at this time appears to have been temporary, there is evidence of a more sustained increase in inflation in Europe proceeding into the early third century.

\section{Conclusion}

Despite the similarity in terms of the scale of the Federal Reserve's quantitative easing in 2020 vs. 2008, it would be a mistake to assume that the monetary and inflation consequences will simply replicate what was seen after the onset of the Global Financial Crisis. Absent the extraordinary surge in bank reserve holding seen in 2008 and after, similarly massive monetary base increases imply a much larger, and potentially worrisome, increase in the money in circulation. Further adding to inflationary concerns is the expansion of Federal Reserve policies into enormous new lending programs that are better characterized as off-balance sheet fiscal policy and credit allocation rather than traditional monetary policy. Unprecedented peacetime deficits in 2020, looking set to rival the deficit to output ratios seen during World War II, represent another constraint on the Federal Reserve's scope for independent action. Should the Federal Reserve attempt to reign in future inflation by reducing the scale of their bond purchases, it is possible that downward pressure on Treasury prices could trigger sharp interest rate increases.

Although a post-coronavirus upsurge in inflation is not inevitable, the expansion in the Federal Reserve's balance sheet is more worrisome than in 2008-2009. Not only are there earlier indications that much more of the new funds will make their way into circulation but also the scope for an unwinding of the ex-

${ }^{10}$ Kallmes (2018: p. 3) has the second debasement occurring a few years earlier, putting it before the plague came to an end in $\mathrm{AD} 180$.

${ }^{11}$ The debasement itself cannot, of course, be assumed to be solely driven by the plague. Howgego et al. (2013), for example, reference the financial pressures of military action against the Parthians as well as metal supply breakdowns. 
pansionary policies may be limited by the new entanglements with fiscal policy and lessened scope for independent action. It is true that inflation initially dropped to $0.2 \%$ in May 2020 in the face of mass shutdowns, forced savings and reduced job security that negatively impacted spending and the velocity of money. Modest as the subsequent steady uptick in inflation to $1.4 \%$ in September 2020 may have been, rising inflation expectations are implied by such phenomena as the surging demand for Treasury Inflation Protected Securities and record highs for gold prices. These trends lend some support to market participants evincing concern that the surging money growth is, in fact, a precursor to future inflation.

Evidence from past pandemics already suggests a further risk due to extra upward pressure on prices arising from pent-up spending after the epidemic has passed. ${ }^{12}$ The scope for identifying causal relationships between money and prices in such earlier episodes as the Antonine Plague and Black Death is admittedly limited by the fragmentary nature of the data. These earlier episodes also featured far higher death tolls than those seen in 2020. However, as with the Spanish Flu, these earlier pandemics each suggest that monetary expansion eventually exerted significant inflationary effects even though these expansions may have involved debasement and increases in money stocks per capita rather than modern-day countercyclical policy. It will likely be years before the full impact of the coronavirus is played out and researchers will be in a position to truly compare it with the earlier pandemics. But it is hard not to be concerned about the scale of the inflationary threat in 2020. In addition to the scope for velocity increasing for existing money balances, the same monetary base will translate into more money in circulation insofar as bank lending rates increase in response to higher demands for funds. This is consistent, for example, with the surge in bank loans following the end of the 1918-1919 Spanish Flu pandemic.

\section{Acknowledgements}

The author thanks Tom Willett, Farrokh Langdana, Dave Dawson and an anonymous referee for helpful comments and suggestions.

\section{Conflicts of Interest}

The author declares no conflicts of interest regarding the publication of this paper.

\section{References}

Anderson, H., Chang, J. W., \& Copeland, A. (2020). The Effect of the Central Bank Liquidity Support during Pandemics: Evidence from the 1918 Spanish Influenza Pan-

\footnotetext{
${ }^{12}$ There is certainly no evidence that pandemics interfere with the inflationary consequences of excess money growth. Similarly, even the strains of being on the losing side of civil war did not preclude the close link between money and price movements seen in connection with the 1864 Confederate currency reform (Burdekin \& Weidenmier, 2001).
} 
demic. Finance and Economics Discussion Series 2020-050, Washington DC: Board of Governors of the Federal Reserve System. https://doi.org/10.17016/FEDS.2020.050

Apergis, E., \& Apergis, N. (2020). Inflation Expectations, Volatility and Covid-19: Evidence from the US Inflation Swap Rates. Applied Economics Letters.

https://doi.org/10.1080/13504851.2020.1813245

BallparksofBaseball.com (nd). 1910-1919 Ballpark Attendance. https://www.ballparksofbaseball.com/1910-1919-mlb-attendance

Barro, R. J., Ursua, J. F., \& Weng, J. (2020). The Coronavirus and the Great Influenza Epidemic: Lessons from the "Spanish Flu" for the Coronavirus's Potential Effects on Mortality and Economic Activity. CESifo Working Paper 8166, Munich.

https://www.cesifo.org/en/publikationen/2020/working-paper/coronavirus-and-great-i nfluenza-epidemic-lessons-spanish-flu

https://doi.org/10.3386/w26866

Bootsma, M. C. J., \& Ferguson, N. M. (2007). The Effect of Public Health Measures on the 1918 Influenza Pandemic in U.S. Cities. Proceedings of the National Academy of Sciences, 104, 7588-7593. https://doi.org/10.1073/pnas.0611071104 https://www.pnas.org/content/suppl/2007/04/09/0611071104.DC1

Burdekin, R. C. K. (2018). Deflations in History. In S. Battilossi, Y. Cassis, \& K. Yago (Eds.), Handbook of the History of Money and Currency (pp. 1-24). New York: Springer. https://doi.org/10.1007/978-981-10-0622-7 49-1

Burdekin, R. C. K. (2020). Death and the Stock Market: International Evidence from the Spanish Flu. Applied Economics Letters.

https://doi.org/10.1080/13504851.2020.1828802

Burdekin, R. C. K., \& Weidenmier, M. D. (2001). Inflation Is Always and Everywhere a Monetary Phenomenon: Richmond vs. Houston in 1864. American Economic Review, 91, 1621-1630. https://doi.org/10.1257/aer.91.5.1621

Christensen, J. H. E., Gamble, J. M., \& Zhu, S. (2020). Coronavirus and the Risk of Deflation. FRBSF Economic Letter, Federal Reserve Bank of San Francisco.

https://www.frbsf.org/economic-research/publications/economic-letter/2020/may/coro navirus-and-risk-of-deflation

Duncan-Jones, R. P. (1996). The Impact of the Antonine Plague. Journal of Roman Archaeology, 9, 108-136. https://doi.org/10.1017/S1047759400016524

Edwards, A. (2020). Policy Responses to the COVID-19 Pandemic. Studies in Applied Economics 151, Baltimore: Johns Hopkins Institute for Applied Economics, Global Health, and the Study of Business Enterprise.

Federal Reserve Bank of St. Louis (2008-2020). Federal Reserve Economic Data (FRED). https://fred.stlouisfed.org

Friedman, M. (2005). A Natural Experiment in Monetary Policy Covering Three Episodes of Growth and Decline in the Economy and the Stock Market. Journal of Economic Perspectives, 19, 145-150. https://doi.org/10.1257/089533005775196787

Friedman, M., \& Schwartz, A. J. (1963). A Monetary History of the United States, 1867-1960. Princeton, NJ: Princeton University Press.

Goodhart, C. (2020). Inflation after the Pandemic: Theory and Practice. Vox, CEPR Policy Portal. https://voxeu.org/article/inflation-after-pandemic-theory-and-practice

Greenwood, J., \& Hanke, S. H. (2020). How the Federal Reserve Can Ease the Coronavirus Panic. Wall Street Journal, March 9.

Grossman, M. (2020). The Covid Surcharge: Companies Confront the Unforgiving Economics of Coronavirus. Wall Street Journal, May 22. 
Harper, K. (2016). People, Plagues, and Prices in the Roman World: The Evidence from Egypt. Journal of Economic History, 76, 803-839. https://doi.org/10.1017/S0022050716000826

Hetzel, R. L. (2020). COVID-19 and the Fed's Credit Policy. Mercatus Working Paper, Arlington, VA: George Mason University. https://doi.org/10.2139/ssrn.3667321 https://www.mercatus.org/publications/covid-19-economic-recovery/covid-19-feds-cre dit-policy

Howgego, C., Butcher, K., Punting, M., \& Heuchert, V. (2013). Coinage and the Roman Economy in the Antonine Period: The View from Egypt. Working Paper, Oxford: Oxford Roman Economy Project, University of Oxford. http://oxrep.classics.ox.ac.uk/docs/Howgego2010.pdf

Jordà, Ò., Singh, S. R., \& Taylor, A. M. (2020). Longer-Run Economic Consequences of Pandemics. Working Paper 26934, Cambridge, MA: National Bureau of Economic Research. https://www.nber.org/papers/w26934

https://doi.org/10.24148/wp2020-09

Kallmes, K. (2018). Imperial Monetary Policy and Social Reaction in Third Century Rome. Journal des Économistes et des Études Humaines, 24, 1-11.

https://doi.org/10.1515/jeeh-2017-0002

Mackenzie, M. (2020.) Investors Need to Decide Whether the Risk of Inflation Is Real. Financial Times, July 17.

McLaughlin, R. (2010). Rome and the Distant East: Trade Routes to the Ancient Lands of Arabia, India, and China. New York: Continuum.

Munro, J. (2004). Before and after the Black Death: Money, Prices, and Wages in Fourteenth-Century England. Working Paper No. 24, Toronto: Department of Economics and Institute for Policy Analysis, University of Toronto.

https://www.economics.utoronto.ca/public/workingPapers/UT-ECIPA-MUNRO-04-0 4.pdf

Paarlberg, D. (1993). An Analysis and History of Inflation. Westport, CT: Praeger.

Rathbone, D. W. (2007). Roman Egypt. In W. Scheidel, I. Morris, \& R. Saller (Eds.), The Cambridge Economic History of the Greco-Roman World (pp. 698-719). Cambridge: Cambridge University Press. https://doi.org/10.1017/CHOL9780521780537.027

Spinney, L. (2017). Pale Rider: The Spanish Flu of 1918 and How It Changed the World. New York: PublicAffairs.

Taubenberger, J. K., \& Morens, D. M. (2006). 1918 Influenza: The Mother of All Pandemics. Emerging Infectious Diseases, 12, 15-22.

https://doi.org/10.3201/eid1209.05-0979

Taylor, J. (1955). Copernicus on the Evils of Inflation and the Establishment of a Sound Currency. Journal of the History of Ideas, 16, 540-547. https://doi.org/10.2307/2707509

Temin, P. (2013). The Roman Market Economy. Princeton, NJ: Princeton University Press.

Terzi, A. (2015). Corridor and Floor Systems. In L.-P. Rochon, \& S. Rossi (Eds.), The Encyclopedia of Central Banking (111-113). Northampton, MA: Elgar.

US Congress (2020). H.R. 748: The Coronavirus Aid, Relief, and Economic Security Act. Washington DC.

Velde, F. R. (2020). What Happened to the US Economy during the 1918 Influenza Pandemic? A View through High-Frequency Data. WP 2020-11, Chicago, IL: Federal Reserve Bank of Chicago. https://doi.org/10.21033/wp-2020-11 https://www.chicagofed.org/publications/working-papers/2020/2020-11 
Wicker, E. R. (1966). A Reconsideration of Federal Reserve Policy during the 1920-1921 Depression. Journal of Economic History, 26, 223-238.

https://doi.org/10.1017/S0022050700068674 